\title{
New index for the diagnosis of liver fibrosis in Schistosomiasis mansoni
}

\author{
Ana Virgínia Matos Sá BARRET01, Vinícius Martins ALECRIM1', Tibério Batista de MEDEIROS², \\ Ana Lúcia Coutinho DOMINGUES², Edmundo Pessoa LOPES², João Roberto Maciel MARTINS³, \\ Helena Bonciani NADER ${ }^{3}$, George Tadeu Nunes DINIZ1 ${ }^{1}$, Silvia Maria Lucena MONTENEGR0 ${ }^{1}$ and \\ Clarice Neuenschwander Lins de MORAIS ${ }^{1}$
}

Received 22/6/2016 Accepted 27/9/2016

\begin{abstract}
Background - Periportal fibrosis is the major pathological consequence of the Schistosoma mansoni infection. Objective - To evaluate the accuracy of serum markers and to construct an index to assess fibrosis. Methods - Patients $(\mathrm{n}=116)$ with schistosomiasis were evaluated by ultrasound scan and measurements of serum levels of aminotransferases, $\gamma$-glutamyl transferase, alkaline phosphatase, hyaluronic acid, cytokines and platelets. Ultrasound images were used to evaluate the fibrosis using Niamey's classification and identified 19 patients without periportal fibrosis (patterns A and B), 48 with mild to moderate fibrosis (C and D) and 49 with advanced fibrosis (E and F). Results - Using multivariate analysis, a model was created, which involved alkaline phosphatase and platelets and could separate patients with different patterns of fibrosis. This index showed a better performance in separating patients without fibrosis from with advanced periportal fibrosis. The biological index showed an area under the ROC curve of 1.000. Using values below the lowest or above the highest cut-off point, the presence or absence of advanced fibrosis could be predicted in all patients. Conclusion - The index constructed can be used to separate patients with different patterns of periportal fibrosis, specially to predict advanced fibrosis in schistosomiasis patients.
\end{abstract}

HEADINGS - Schistosomiasis mansoni. Fibrosis. ROC curve analysis.

\section{INTRODUCTION}

In chronic infection by Schistosoma mansoni the liver is the main organ affected, because soon after oviposition by females worms in the mesenteric veins, the eggs are carried by the bloodstream into the liver. Several eggs are trapped in small venules of the liver, triggering a vigorous immune response with granuloma formation ${ }^{(1,2)}$. Continuous oviposition and formation of new granulomas around the eggs lead to excessive deposition of collagen and other components of the extracellular matrix in the intrahepatic branches of the portal vein, which causes periportal fibrosis (PPF), a pathognomonic sign of Schistosomiasis mansoni disease. Moreover, PPF induces the appearance of hemodynamic alterations $^{(26,33)}$.

The accumulation of fibrotic tissue as a result of granuloma, decreases the elasticity of the veins and contributes to the obstruction the portal blood flow, resulting in portal hypertension and its consequences (esophageal varices), which leads to morbidity and mortality associated with schistosomiasis ${ }^{(7)}$.

The diagnosis of PPF was undertaken using imaging methods such as ultrasound (US), computed tomography and magnetic resonance imaging. Of these, US is the most widely used in Brazil, because of its low cost ${ }^{(4,10)}$. Furthermore, Homeida et al. ${ }^{(15)}$ demonstrated that US is as sensitive as liver wedge biopsy in diag- nosing PPF. Despite the widespread use of US for diagnosing and monitoring changes caused by fibrosis, its use has some limitations, such as its low sensitivity in the initial forms of the disease; the need for a trained examiner, and the fact that it is not available at all centers, especially not those located in rural areas ${ }^{(17)}$.

As a result of these US limitations, studies are emerging in an attempt to develop non-invasive methods that are capable of identifying and evaluating PPF via serum markers ${ }^{(6,9,16,21,25,28,30)}$. In Brazil, it is estimated that the Schistosomiasis mansoni affects about 2.5 to 6 million individuals, residing mainly in the Northeastern region, and approximately $5 \%$ to $10 \%$ of whom will develop the severe form of the disease (hepatosplenic) ${ }^{(5)}$. Therefore, the study of new methods for diagnosing and evaluating PPF is important so as to provide information for designing strategies to treat and prevent the evolution of the disease.

Different biological markers have been associated with the development and regulation of hepatic fibrosis in some chronic liver diseases, especially those induced by the hepatitis $\mathrm{C}$ virus $(\mathrm{HCV})^{(11,24)}$. These serum markers have been used in combination to improve their accuracy, as in the case of the FibroTest ${ }^{(27)}, \mathrm{APRI}^{(35)}$, the Forns index ${ }^{(13)}$, Hepascore ${ }^{(1)}$, and FIB- $4^{(32)}$. However, only one article found in their review of the literature uses the APRI index ${ }^{(17)}$ and no articles were found that described a specific index for evaluating PPF in patients with Schistosomiasis mansoni.

Declared conflict of interest of all authors: none

Disclosure of funding: FACEPE and CNPq

${ }^{1}$ Centro de Pesquisas Aggeu Magalhães, Fundação Oswaldo Cruz, Recife, PE, Brasil; ${ }^{2}$ Departamento de Medicina Clínica, Universidade Federal de Pernambuco, Recife, PE, Brasil; ${ }^{3}$ Departamento de Bioquímica, Disciplina de Biologia Molecular, Escola Paulista de Medicina, Universidade Federal de São Paulo, SP, Brasil.

Correspondence: Clarice Neuenschwander Lins de Morais. Fundação Oswaldo Cruz, Centro de Pesquisas Aggeu Magalhães Av. Moraes Rego s/n, Cidade Universitária - CEP: 50670-420 Recife, PE, Brasil. E-mail: clarice@cpqam.fiocruz.br 
This paper therefore set out to evaluate the accuracy of serum markers and to construct a biological index to assess PPF in patients with Schistosomiasis mansoni.

\section{METHODS}

\section{Patients}

Patients of both genders aged between 18 and 65 years old, diagnosed as having Schistosomiasis mansoni were evaluated between July 2009 and August 2010, at the Schistosomiasis outpatient clinic of the Hospital das Clínicas (HC) at the at the Universidade Federal de Pernambuco (UFPE). The diagnosis was based on their clinical history of contact with contaminated water and/or reports of prior treatment for schistosomiasis and US examination of the upper abdomen. Patients who reported no prior treatment or whose parasitological stool test was positive for schistosomiasis were treated and evaluated 6 months after this treatment.

During the period in which patients were selected at the University Hospital as subject to developing chronic forms of schistosomiasis, 892 ultrasound examinations of the upper abdomen were conducted. Of these, 116 were included in the study and 776 were excluded as per the following exclusion criteria: a clinical, laboratory or US diagnosis compatible with hepatic diseases of other etiologies (hepatitis $\mathrm{B}$ or $\mathrm{C}$, hepatic cirrhosis or fatty liver disease), excessive consumption of ethanol, use of immunosuppressive or hepatotoxic drugs, liver transplant, chronic kidney disease and prior splenectomy.

\section{Ethics statement}

All clinical investigation was conducted according to the principles expressed in the Declaration of Helsinki. All patients signed a term of consent and the study was approved by the Ethics Committee of CPqAM-FIOCRUZ, report No 44/03.

\section{Ultrasound}

The pattern of PPF was evaluated by upper abdominal US examination at the Keizo Asami Laboratory of Immunopathology at HC-UFPE. A Siemens Acuson X $150^{\circledR}$ with a $3.5 \mathrm{MHz}$ convex transducer was used for all patients by the same researcher (ALCD), following the Niamey classification ${ }^{(29)}$. This classification characterizes the PPF in terms of six patterns: A (absent), B (doubtful), $\mathrm{C}$ (peripheral), D (central), E (advanced) and F (very advanced).

\section{Biomarkers}

After the US evaluation, $10 \mathrm{~mL}$ of blood was collected from each patient to determine the serum levels of alanine aminotransferase (ALT), aspartate aminotransferase (AST), $\gamma$-glutamil transferase $(\gamma-G T)$ and alkaline phosphatase (AP) in the Biochemistry Laboratory of the HC-UFPE using an automated ARCHITECT - UV DiaSys by Siemens Automation - Dimension. The serum levels of the markers were divided by the upper limit of normality (ULN) and expressed as UI/mL/ULN. The platelet count ( $\mathrm{x} 10^{9} \mathrm{cel} /$ $\mathrm{mm}^{3}$ ) was conducted using an automated counter (CELL DYN 3000 ) at the Hematology Laboratory of the HC-UFPE.

To measure hyaluronic acid (HA ng/mL), an aliquot $(500 \mu \mathrm{L})$ of serum from each patient was stored at $-20^{\circ} \mathrm{C}$ and sent it was sent to be measurement at the Molecular Biology Unit at the Department of Biochemistry of the Universidade Federal de São Paulo (UNIFESP). HA was measured by an immunofluorometric method which was non-competitive and ELISA-like, based on the affinity of HA for specific proteins in the cartilage ${ }^{(22)}$.
The serum levels of TNF- $\alpha$, TGF- $\beta$ and IL-13 (pg/mL) were measured using the R\&D Systems Quantikine kit, as per the supplier's instructions, in the Laboratory of Immunology and Molecular Biology, at the Department of Immunology of the CPqAM-FIOCRUZ

\section{Statistical analysis}

The patients were divided into four groups as per the PPF pattern using Niamey's classification. Group 1 consisted of patients without PPF (patterns A and B). Group 2 of patients with PPF (patterns $C, D, E$ and $F$ ), group 3 of patients with mild to moderate PPF (patterns $C$ and D) and group 4 of patients with advanced PPF (patterns E and F).

The SPSS for Windows, version 18.0 - Statistical Package for The Social Science was used to perform statistical calculations. Quantitative variables were expressed as the median, 25 percentile and 75 percentile. To identify the predictor factors of fibrosis, an univariate analysis of the variables of interest was performed using the nonparametric Mann-Whitney test due to non-normality of the variables quantitative. Subsequently, a multivariate analysis was performed using logistic regression model with the dependent variable groups of fibrosis. The independent or explanatory variables considered in the model were those with $P<0.25$ in the univariate analysis, this probability was set for possible predictors of events were not excluded from the analysis. In the model the forward stepwise method for selection of variables in the model was used.

The diagnostic value was assessed using the ROC curve and the sensitivity, specificity and the positive and negative predictive values (PPV; NPV) were determined. The area under the curve was used to represent the accuracy of the predictions.

\section{RESULTS}

\section{Characteristics of the patients}

Of the 116 patients included in the study, 19 (16.4\%) were classified with PPF patterns A and B; 48 (41.4\%) with patterns $\mathrm{C}$ and D; and $49(42.2 \%)$ with patterns $\mathrm{E}$ and $\mathrm{F}$. In the group comprising the A and B patterns, $5(26.3 \%)$ patients were male and $14(73.7 \%)$ were female. In the group consisting of the $\mathrm{C}$ and D patterns, $14(29.2 \%)$ were male and $34(70.8 \%)$ female, and in the group comprising the E and F patterns, 24 (49\%) were male and $25(51 \%)$ were female. There was no significant difference with regard to gender between the groups. The average age in the three groups $(\mathrm{A}+\mathrm{B}, \mathrm{C}+\mathrm{D}$ and $\mathrm{E}+\mathrm{F})$ was $43.3,46.4$ and 52.1 years old respectively, with a statistical difference between the $\mathrm{A}+\mathrm{B}$ and $\mathrm{E}+\mathrm{F}$ groups $(P=0.026)$.

\section{Relationship between the serum levels of markers with the patterns of periportal fibrosis}

Table 1 presents the univariate analysis of biomarker serum levels of the 116 patients.

According to the results of univariate analysis, only TNF- $\alpha$ and IL-13 markers showed no statistically significant difference between groups. Thus, all other variables were considered in the multivariate logistic regression model. In the model the forward stepwise method for selection of variables was used. However, in the final model only the AP $(P=0.035)$ and number of platelets $(P=0.0004)$ were significant variables for prediction of periportal fibrosis. A model was created to identify and differentiate the groups of patients without fibrosis, with mild to moderate and 
TABLE 1. Univariate analysis of serum levels of biomarkers in 116 patients with schistosomiasis mansoni

\begin{tabular}{|c|c|c|c|c|}
\hline \multirow[b]{2}{*}{ Biomarkers } & \multicolumn{3}{|c|}{ Periportal fibrosis group } & \multirow[b]{2}{*}{$P$ value* } \\
\hline & $\begin{array}{c}\mathrm{A}+\mathrm{B} \text { (median) } \\
\mathrm{n}=19\end{array}$ & $\begin{array}{c}\mathrm{C}+\mathrm{D} \\
(\text { median }) \\
\mathrm{n}=48\end{array}$ & $\begin{array}{c}\mathbf{E}+\mathbf{F} \\
(\text { median}) \\
\mathrm{n}=49\end{array}$ & \\
\hline Alanine aminotransferase (/ULN) & $\begin{array}{c}0.61 \\
(0.45-0.71)\end{array}$ & $\begin{array}{c}0.67 \\
(0.46-0.92)\end{array}$ & $\begin{array}{c}0.77 \\
(0.61-1.12)\end{array}$ & $0.0052^{\mathrm{b}}$ \\
\hline Aspartate aminotransferase (/ULN) & $\begin{array}{c}0.61 \\
(0.52-0.71)\end{array}$ & $\begin{array}{c}0.75 \\
(0.58-1.05)\end{array}$ & $\begin{array}{c}0.87 \\
(0.71-1.13)\end{array}$ & $<0.001^{\mathrm{b}}$ \\
\hline$\gamma$-Glutamyl transferase (/ULN) & $\begin{array}{c}0.55 \\
(0.38-074)\end{array}$ & $\begin{array}{c}0.87 \\
(0.49-1.94)\end{array}$ & $\begin{array}{c}1.52 \\
(0.92-3.13)\end{array}$ & $<0.001^{\mathrm{b}}$ \\
\hline Hyaluronic acid (ng/mL) & $\begin{array}{c}22.5 \\
(19-37.1)\end{array}$ & $\begin{array}{c}32.7 \\
(20.7-50.6)\end{array}$ & $\begin{array}{c}67.8 \\
(37.6-102.8)\end{array}$ & $<0.001^{\mathrm{b} ; \mathrm{c}}$ \\
\hline TNF- $\alpha(\mathrm{pg} / \mathrm{mL})$ & $1.5(0-2.2)$ & $0.8(0-4.4)$ & $1.5(0-4.7)$ & - \\
\hline IL-13 (pg/mL) & $\begin{array}{c}26.4 \\
(20.4-42.8)\end{array}$ & $\begin{array}{c}26.6 \\
(16.7-38.4)\end{array}$ & $\begin{array}{c}26.4 \\
(15-5-39-8)\end{array}$ & - \\
\hline TGF- $\beta(\mathrm{pg} / \mathrm{mL})$ & $\begin{array}{c}58.350 \\
(40.698-74.929)\end{array}$ & $\begin{array}{c}35.534 \\
(14.085-56.575)\end{array}$ & $\begin{array}{c}23.793 \\
(14.442-36.410)\end{array}$ & $<0.001^{\mathrm{b}}$ \\
\hline
\end{tabular}

$\mathrm{A}+\mathrm{B}=$ without PPF $\mathrm{C}+\mathrm{D}=$ mild to moderate PPF; E+F = advanced PPF; ULN: upper limit of normality; $*$ Mann-Whithey test; Median $\left(\mathrm{P}_{25}-\mathrm{P}_{75}\right){ }^{\text {a }} \mathrm{A}+\mathrm{B} \times \mathrm{C}+\mathrm{D} ;{ }^{\mathrm{b}} \mathrm{A}+\mathrm{B} \times \mathrm{E}+\mathrm{F} ;{ }^{\mathrm{c}} \mathrm{C}+\mathrm{D} \times \mathrm{E}+\mathrm{F}$.

advanced PPF. The index involved AP and platelet count. Analysing this model, a biological index was constructed and named the Coutinho-index.

The name Coutinho-index was in honor of Professor Amaury Domingues Coutinho, an example of a great research scientist and driving force behind much research in the area of Schistosomiasis mansoni in Brazil, principally in our region.

Risk score was determined using the following regression formulae:

Coutinho-index risk score $=\mathrm{e}^{(17.25+0.067 \times \mathrm{AP}-0.133 \times \text { platelet })}$
Since AP and platelet count were the most important predictors for fibrosis and they are inversely proportional behavior towards periportal fibrosis, this index was therefore constructed to assess the absence of PPF $(\mathrm{A}+\mathrm{B})$ or the presence of advanced PPF $(\mathrm{E}+\mathrm{F})$ using the following formulae:

Coutinho-index $=\mathrm{AP}(/ \mathrm{ULN}) /$ platelet count $\left(\times 10^{9} \mathrm{cel} / \mathrm{mm}^{3}\right) \times 100$

The Coutinho-index can predict the presence of PPF in the four groups analysed in this study (Table 2). In addition, the index plays a better accurate to differentiate patients without PPF (patterns A

TABLE 2. Performance of the Coutinho-index as predictors of the periportal fibrosis patterns in 116 schistosomiasis patients

\begin{tabular}{|c|c|c|c|c|c|c|c|}
\hline & $\begin{array}{c}A+B \\
(n=19)\end{array}$ & $\begin{array}{c}\mathrm{C}+\mathrm{D}+\mathrm{E}+\mathrm{F} \\
(\mathrm{n}=97)\end{array}$ & AUC & Sensitivity & Specificity & PPV & NPV \\
\hline & $\mathrm{n}(\%)$ & $\mathrm{n}(\%)$ & $(95 \% \mathrm{CI})$ & $(95 \% \mathrm{CI})$ & $(95 \% \mathrm{CI})$ & $(\%)$ & $(\%)$ \\
\hline Coutinho-index & & & 0.907 & & & & \\
\hline Cut off & & & & & & & \\
\hline$\geq 0.043$ & $\frac{1(1.3)}{A+B}$ & $\frac{81(83.5)}{C+D}$ & & & & & \\
\hline & $(n=19)$ & $(n=48)$ & AUC & Sensitivity & Specificity & PPV & NPV \\
\hline$<0.038$ & $14(73.7)$ & $18(37.5)$ & & 62.5 & 73.7 & 85.7 & 43.8 \\
\hline$\geq 0.038$ & $5(26.3)$ & $30(62.5)$ & & & & & \\
\hline & $\begin{array}{c}A+B \\
(n=19)\end{array}$ & $\begin{array}{c}\mathrm{E}+\mathrm{F} \\
(\mathrm{n}=49)\end{array}$ & AUC & Sensitivity & Specificity & PPV & NPV \\
\hline & $\mathrm{n}(\%)$ & $\mathrm{n}(\%)$ & $(95 \% \mathrm{CI})$ & $(95 \% \mathrm{CI})$ & $(95 \% \mathrm{CI})$ & $(\%)$ & $(\%)$ \\
\hline Coutinho-index & & & 1.000 & & & & \\
\hline & $\mathrm{n}(\%)$ & $\mathrm{n}(\%)$ & $(95 \% \mathrm{CI})$ & $(95 \% \mathrm{CI})$ & $(95 \% \mathrm{CI})$ & $(\%)$ & $(\%)$ \\
\hline Coutinho-index & & & 0.859 & & & & \\
\hline Cut off & & & & & & & \\
\hline$<0.060$ & $29(60.4)$ & 0 & & 93.9 & 64.6 & 72.1 & 100 \\
\hline$\geq 0.060$ & $19(36.9)$ & $49(100)$ & & & & & \\
\hline
\end{tabular}

Coutinho- index = AP $(/ \mathrm{ULN}) /$ Platelet count $\left(\mathrm{x} 10^{9} \mathrm{cel} / \mathrm{mm}^{3}\right) \times 100 . \mathrm{A}+\mathrm{B}=$ without PPF; $\mathrm{C}+\mathrm{D}+\mathrm{E}+\mathrm{F}=$ with PPF; $\mathrm{C}+\mathrm{D}=\mathrm{mild}$ to moderate PPF; $\mathrm{E}+\mathrm{F}=$ advanced PPF. PPV: positive predictive value; NPV: negative predictive value. 
and B) of the patients with advanced PPF (patterns E and F) in compared to other groups. Based on the ROC curve, to predict the absence of PPF (patterns A and B) was established a cut-off point $<0.048$ and to predict the presence of advanced PPF (patterns E and $F$ ) was establish a cut-off point $>0.048$. Of the 19 patients who were diagnosis without fibrosis, all $(100 \%)$ presented a result at Coutinho-index $<0.048$, and all 49 patients $(100 \%)$ who were diagnosed with advanced PPF, showed results $>0.048$, in agreement with the diagnosis through the ultrasound examination (Table 2).

The Coutinho-index in comparison with the isolates biological markers revealed an area under the ROC curve a few better (AUC index $=1.00 ; \mathrm{AP}=0.971 ;$ platelet count $=0.997)$, suggesting that the use of markers as an index increases to predict the advanced fibrosis in patients with Schistosomiasis mansoni.

As showing in Figure 1, the Coutinho-index presented higher sensitivity and specificity value (100\%, both) and a higher negative and positive predictive value $(100 \%$, both) in separating patients without PPF from those with advanced PPF.

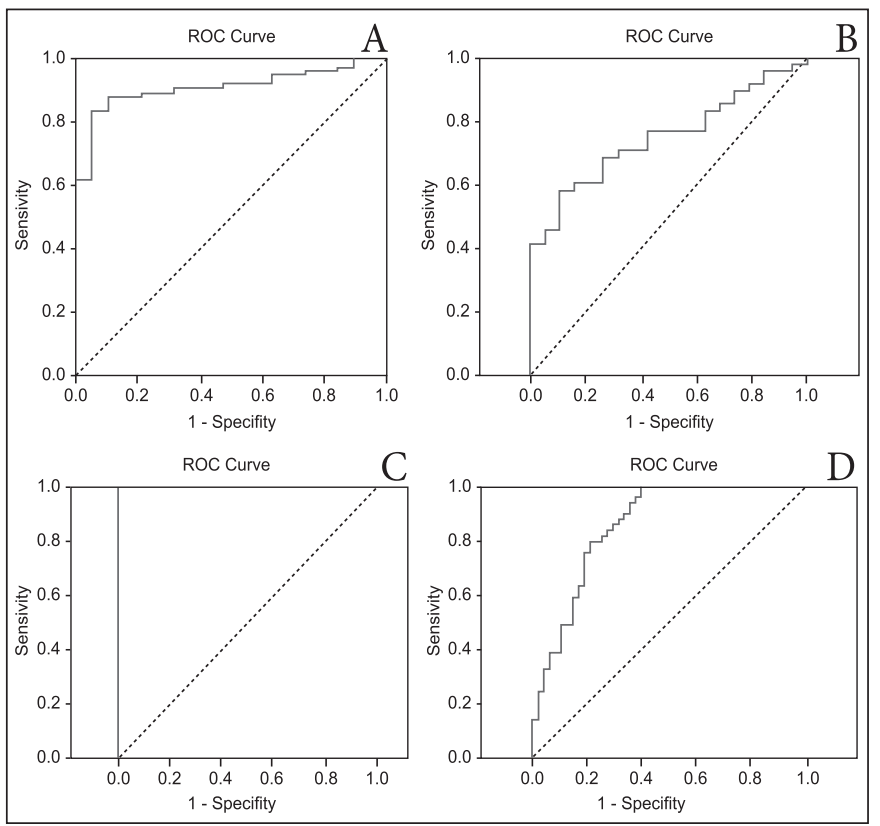

FIGURE 1 - Coutinho-index ROC curves for groups of periportal fibrosis in Schistosomiasis mansoni patients. A) $\mathrm{A}+\mathrm{B} \times \mathrm{C}+\mathrm{D}+\mathrm{E}+\mathrm{F}$. $\mathrm{AUC}=0.907$. B) $\mathrm{A}+\mathrm{B} \times \mathrm{C}+\mathrm{D} . \mathrm{AUC}=0.750$. C) $\mathrm{A}+\mathrm{B} \times \mathrm{E}+\mathrm{F} . \mathrm{AUC}=1.00$. D) $\mathrm{C}+\mathrm{D} \times \mathrm{E}+\mathrm{F}$ $\mathrm{AUC}=0.859 . \mathrm{A}+\mathrm{B}=$ without $\mathrm{PPF} ; \mathrm{C}+\mathrm{D}+\mathrm{E}+\mathrm{F}=$ with $\mathrm{PPF} ; \mathrm{C}+\mathrm{D}=$ mild to moderate $\mathrm{PPF} ; \mathrm{E}+\mathrm{F}=$ advanced $\mathrm{PPF}$

\section{DISCUSSION}

In recent years, non-invasive markers have been used to draw up biological indexes to diagnose hepatic fibrosis. However, these indexes were developed and tested in patients with chronic liver disease, usually induced by $\mathrm{HCV}$, and some caution should be exercised when considering extrapolating them to other hepatic fibrogenic diseases ${ }^{(14)}$. The aim of the present study was thus to evaluate serum markers and develop a biological index to assess liver fibrosis in Schistosomiasis mansoni.

In the multivariate analysis, AP and Platelet count markers were the independent variables which were used to develop a biological index to distinguish patients with different pattern of periportal fibrosis, in which outperformed in separating patients without PPF (pattern A+B) from those with advanced PPF (pattern $E+F$ ).

The serum levels of AP and Platelet count, in isolation, have been associated with advanced PPF in previous studies. The AP enzyme is a marker serum of cholestatic abnormalities and is useful when seeking to diagnose chronic liver diseases. Morais et al. ${ }^{(25)}$ showed that this enzyme as an accurate marker to predict moderate and severe fibrosis in patients with hepatitis $\mathrm{C}$. With regard to schistosomiasis, a study described by Leite et al. ${ }^{(18)}$ with 55 hepatosplenic patients, they found the prevalence of advanced fibrosis in 54.5\% of patients and compared them to healthy individuals, the levels of AP presented significantly elevated $(P<0.0001)$. Other studies with hepatosplenic patients, they showed a significant increase in serum levels of AP in relation to control groups ${ }^{(19,20)}$. In schistosomiasis, the changes of the intrahepatic biliary tree, either by ductal injuries caused by ovular reactions or arising from of PPF, could be the anatomical substrate for the increase of this enzyme ${ }^{(3,34)}$.

The platelet count in the blood has been an indicator of severity in schistosomiasis by increasing the risk of bleeding, with its numerical reduction related to the presence of portal hypertension ${ }^{(8,31)}$ and $\mathrm{PPF}^{(7)}$. Some schistosomiasis studies that evaluated platelets and other serum markers have reported lower platelet levels in patients with more advanced fibrosis ${ }^{(2,12,16)}$.

Lambertucci et al. ${ }^{(17)}$ conducted a study involving 47 hepatosplenic patients and 13 with the hepatointestinal schistosomiasis. The authors correlated the different degrees of PPF with the number of platelets and concluded that the use of platelet count as a biomarker in the blood is promising to predict periportal fibrosis, because it is a low-cost and non-invasive marker of fibrosis caused by Schistosoma mansoni and can also help to define the degree of liver involvement. Another study conducted with 122 patients with schistosomiasis showed a significant negative correlation with the different patterns of PPF. The more advanced stages of fibrosis were associated with lower platelet count compared to the group of patients without fibrosis ${ }^{(23)}$.

The Coutinho-index presented in this study showed significant accuracy $(\mathrm{AUC}=1.000)$ since it distinguished schistosomiasis patients without advanced fibrosis from those with advanced fibrosis. This suggests that the use of biological markers together, as an index, provides greater accuracy in diagnosing PPF rather than biomarkers isolated.

The results observed using the Coutinho-index to diagnose advanced PPF were similar to those of other indexes designed to assess advanced fibrosis in other liver diseases. The APRI index showed an AUC of 0.80 with a PPV of $88 \%$ and a NPV of $86 \%$ to predict and exclude the presence, respectively, of significant fibrosis in patients with liver disease induced by $\mathrm{HCV}^{(35)}$. The same index was also applied to a sample of schistosomiasis patients and presented a ROC curve of 0.96 with $96 \%$ sensitive and $85 \%$ specific $^{(17)}$. When another index, Hepascore (bilirubin, $\gamma$-GT, HA, $\alpha 2$-macroglobulin, age and gender), was used, an AUC of 0.95 with a sensitivity and specificity of $95 \%$ and $81 \%$, respectively, which identified the presence of advanced fibrosis, was observed in the training group ${ }^{(1)}$.

In addition, Countinho-index exhibited a sensitivity of $100 \%$ and the same specificity (100\%). The NPV and PPV of index were higher also (100\%), showing a higher accuracy in distinguishing between patients without from those with advanced PPF.

Nonetheless, the patients evaluated in our study came from a specialized hospital, where the most advanced cases of the disease are found. To overcome these limitations, Coutinho-index is in 
a validated process using a large number of schistosomiasis patients of the endemic area. Therefore, further studies are needed to confirm our findings.

The index drawn up in the present study has a number of advantages, such as its simplicity of use and low cost in relation to the structure needed to conduct the US examination, especially in small centers in endemic areas, and could well be included among the exams used for evaluating PPF. The evaluation of advanced PPF using the biological index proposed should be less expensive and more convenient than the use of US, since serum levels of AP and platelet count are routine tests in patients infected with $S$. mansoni to analyze liver involvement.

\section{CONCLUSION}

This study developed an index, deemed the Coutinho-index, which could be used to distinguish patients with different pattern of PPF with a better performance in predict the presence of advanced fibrosis in schistosomiasis patients.

\section{Authors' contributions}

Barreto AVMS and Alecrim VM performed the research. Medeiros TB, Domingues ALC and Lopes EP contributed with the patient selection for the study. Martins JRM and Nader HB contributed with the measure hyaluronic acid. Diniz GTN contributed with the statistical analysis. Barreto AVMS, Montenegro SML, Lopes EP and Morais CNL analysed the data and wrote the paper. All authors revised the manuscript and approved the submitted final version of the manuscript.

\section{ACKNOWLEDGEMENTS}

The authors thank to CNPq and FACEPE for the financial support.

Barreto AVMS, Alecrim VM, Medeiros TB, Domingues ALC, Lopes EP, Martins JRM, Nader HB, Diniz GTN, Montenegro SML, Morais CNL. Novo índice biológico para o diagnóstico da fibrose hepática na Esquistossomose mansoni. Arq Gastroenterol. 2017,54(1):51-6.

RESUMO - Contexto - A fibrose periportal é a maior consequência patológica da infecção pelo Schistosoma mansoni. Objetivo - Avaliar a acurácia de marcadores séricos e construir um índice para avaliar a fibrose. Métodos - Pacientes $(n=116)$ com esquistossomose foram avaliados pela ultrassonografia e dosados os níveis de aminotransferases, $\gamma$-glutamil transferase, fosfatase alcalina, ácido hialurônico, citocinas e plaquetas. Imagens de ultrasom foram utilizadas para avaliar a fibrose através de classificação de Niamey e identificados 19 pacientes sem fibrose periportal (padrão A e B), 48 com fibrose média a moderada (C e D) e 49 com fibrose avançada (E e F). Resultados - Através de análise multivariada, um modelo foi criado, que envolveu a fosfatase alcalina e plaquetas e conseguiu separar pacientes com diferentes padrões de fibrose periportal. Este índice mostrou um melhor desempenho em separar pacientes sem fibrose dos pacientes com fibrose avançada. O índice biológico mostrou uma área sob a curva ROC de 1,000. Usando valores infereiores e acima do ponto de corte, a presença ou ausência de fibrose avançada pode ser prevista em todos os pacientes. Conclusão - O índice construído pode ser usado para separar os pacientes com diferentes padrões de fibrose periportal, especialmente para prever fibrose avançada em pacientes com esquistossomose.

DESCRITORES - Esquistossomose mansoni. Fibrose. Curva ROC.

\section{REFERENCES}

1. Adams LA, Bulsara M, Rossi E, DeBoer B, Speers D, et al. Hepascore: An Accurate Validated Predictor of Liver Fibrosis in Chronic Hepatitis C Infection. Clin Chem. 2005;51:1867-73.

2. Al Mofarreh MA, Al Akwaa AY, Al Mofleh IA. Gammaglutamyl transpeptidase activity in patients with schistosomiasis. Saudi J Gastroenterol. 2003;9:15-9.

3. Alves-Junior A, Fontes DV, Melo VA, Machado MCC, Cruz JF, et al. Hipertensão portal esquistossomótica: influência do fluxo sanguíneo portal nos níveis séricos das enzimas hepáticas. Arq Gastroenterol. 2003;40:203-8.

4. Andrade, ZA. Schistosomiasis and hepatic fibrosis regression. Acta Trop. 2008;108:79-82.

5. Brasil. Ministério da Saúde. Secretaria de Vigilância em Saúde. Departamento de Vigilância em Doenças Transmissíveis. 2012. Plano integrado de ações estratégicas de eliminação da hanseníase, filariose, esquistossomose e oncocercose como problema de saúde pública, tracoma como causa de cegueira e controle das geohelmintíases: plano de ação 2011-2015. Brasília: Ministério da Saúde.

6. Buchard GD, Guissé-Sow F, Diop M, Ly A, Lanuit R, et al. Schistosoma mansoni infection in a recently exposed community in Senegal: lack of correlation between liver morphology in ultrasound and connective tissue metabolites in serum. Trop Med Inter Health. 1998;3:234-41.

7. Burke ML, Jones MK, Gobert GN, Li YS, Ellis MK, et al. Immunopathogenesis of human schistosomiasis. Parasite Immunol. 2009;31:163-76.

8. Correia MCB, Domingues ALC, Lacerda HR, Santos EM, Machado CGF, Hora V, et al. Platelet function and the von Willebrand factor antigen in the hepatosplenic form of schistosomiasis mansoni. Trans R Soc Trop Med Hyg. 2009; $103: 1053-8$
9. Correia HST, Domingues ALC, Lopes EPA, Morais CNL, Sarteschi C, et al. Níveis séricos de globulinas e a intensidade da fibrose hepática em pacientes com esquistossomose mansônica. Arq Gastroenterol. 2009;46:194-8.

10. Domingues AL, Lima ARF, Dias HS, Leao GC, Coutinho A. An ultrasonographic study of liver fibrosis in patients infected with Schistosoma mansoni in north-east Brazil. Trans Royal Soc Trop Med Hyg. 1993;87:555-8.

11. EASL-European Association for the Study of the Liver. Clinical Practice Guidelines: Non-invasive tests for evaluation of liver disease severity and prognosis. J Hepatol. 2015;63:237-64.

12. el-Shorbagy E, Afefy AF, Ibrahem IA, Mangoud AM, Eissa MH, et al. Non-invasive markers and predictors of severity of hepatic fibrosis in HCV patients at Sharkia Governorate, Egypt. J Egypt Soc Parasitol. 2004;34:459-78.

13. Forns X, Ampurdamès S, Llovet JM, Aponte J, Quintó L, et al. Identification of chronic hepatitis $\mathrm{C}$ patients without hepatic fibrosis by a simple predictive model. Hepatology. 2002;36:986-92.

14. Gressner OA, Weiskirchen R, Gressner AM. Biomarkers of liver fibrosis: Clinical translation of molecular pathogenesis or based on liver-dependent malfunction tests. Clin Chim Acta. 2007;38:107-13.

15. Homeida M, Abdel-Gadir AF, Cheever AW, Bennett JL, Arbab BM, et al. Diagnosis of pathologically confirmed Symmers' periportal fibrosis by ultrasonography: a prospective blinded study. Am J Trop Med Hyg. 1998;38:86-91.

16. Köpke-Aguiar LA, Martins JRM, Passerotti CC, Toledo CF, Nader HB, et al. Serum hyaluronic acid as a comprehensive marker to access severity of liver disease in schitosomiasis. Acta Trop. 2002;84:117-26. 
17. Lambertucci JR, Silva LCS, Antunes CM. Aspartate aminotransferase to platelet ratio index and blood platelet count are good markers for fibrosis evaluation in schistosomiasis mansoni. Rev Soc Bras Med Trop. 2007;40:599.

18. Leite LAC, Pimenta-Filho AA, Fonseca CSM, Santos BS, Ferreira RCS, et al. Hemostatic dysfunction is increased in patients with hepatosplenic schistosomiasis mansoni and advanced periportal fibrosis. PLOS Neglected Tropical Diseases 2013;7:1-5.

19. Leite LAC, Domingues ALC, Lopes EP, Ferreira RCS, Filho AAP, Fonseca CSM, et al. Relationship between splenomegaly and hematologic findings in patients with hepatosplenic schistosomiasis. Rev Bras Hematol Hemoter. 2013;35:332-6.

20. Leite LAC, Pimenta Filho AA, Fereira RCS, Fonseca CSM, Santos BS, Montenegro SML, et al. Splenectomy improves hemostatic and liver functions in hepatosplenic Schistosomiasis mansoni. PloS ONE. 2015;10:1-10.

21. Marinho CC, Bretas T, Voieta I, Queiroz LC, Ruiz-Guevara R, et al. Serum hyaluronan and collagen IV as non-invasive markers of liver fibrosis in patient from an endemic area for schistosomiasis mansoni: a field-based study in Brazil. Mem Inst Oswaldo Cruz. 2010;105:471-8.

22. Martins JRM, Passerotti CC, Maciel RM, Sampaio LO, Dietrich CP, et al. Practical determination of hyaluronan by a new noncompetitive fluorescence-based assay on serum of normal and cirrhotic patients. Anal Biochem. 2003;319:65-72.

23. Medeiros TB, Domingues ALC, Luna CF, Lopes EP. Correlation between platelet count and both liver fibrosis and spleen diameter in patients with schistosomiasis mansoni. Arq Gastroenterol. 2014;51:34-8

24. Merli M, Galli L, Castagna A, Salpietro S, Gianotti N, Messina E, Poli A, et al. Diagnostic accuracy of APRI, FIB-4 and Forns for the detection of liver cirrhosis in HIV/HCV-coinfected patients. New Microbiologica. 2016;39:110-3

25. Morais CNL, Carvalho BM, Melo WG, Melo FL, Lopes EP, et al. Correlation of biological serum markers with the degree of hepatic fibrosis and necroinflammatory activity in hepatitis $\mathrm{C}$ and schistosomiasis patients. Mem Inst Oswaldo Cruz. 2010;105:460-6.
26. Pearce EJ, MacDonald AS. The immunobiology of schistosomiasis. Nat Rev Immunol. 2002;2:499-511.

27. Poynard T, McHutchison J, Manns M, Myers RP, Albrecht J. Biochemical Surrogate Markers of Liver Fibrosis and Activity in a Randomized Trial of Peginterferon Alfa-2b and Ribavirin. Hepatology. 2003;38:481-92.

28. Ricard-Blum S, Hartmann DJ, Grenard P, Ravaoalimalala VE, Boisier P, et al Relationships between several markers of extracellular matrix turn-over and ultrasonography in human schistosomiasis mansoni. Am J Trop Med Hyg. 1999;60:658-63.

29. Richter J, Domingues ALC, Barata CH, Prata AR, Lambertucci, JR. Report of the Second Satellite Symposium on Ultrasound in schistosomiasis. Mem Inst Oswaldo Cruz. 2001;96:151-6.

30. Silva CC, Domingues AL, Lopes EP, Morais CN, Santos RB, et al. Schistosomiasis mansoni: ultrasound- evaluated hepatic fibrosis and serum concentrations of hyaluronic acid. Ann Trop Med Parasitol. 2011;105:233-9.

31. Souza MR, Toledo CF, Borges DR. Trombocytemia as a predictor of portal hypertension in schistosomiasis. Dig Dis Sci. 2000;45:1964-70.

32. Sterling RK, Lissen E, Clumeck N, Sola R, Correa MC, et al. Development of a Simple Noninvasive Index to Predict Significant Fibrosis in Patients With HIV/ HCV Coinfection. Hepatology. 2006;43:1317-25.

33. Vezozzo DC, Farias AQ, Cerri GG, Da Silva LC, Carrilho FJ Assessment of portal hemodynamics by Doppler ultrasound and of liver morphology in the hepatosplenic and hepatointestinal forms of schistosomiasis mansoni. Dig Dis Sci. 2006;51:1413-9.

34. Vianna MR, Gayotto LC, Telma R, Santos M, Alves VA, et al. Intrahepatic bile duct changes in human hepatosplenic schistosomiasis mansoni. Liver. 1989;9:100-9.

35. Way CT, Greenson JK, Fontana RJ, Kalbfleisch JD, Marrero JA, et al. A simple noninvasive index can predict both significant fibrosis and cirrhosis in patients with chronic hepatitis C. Hepatology. 2003; 38:518-26. 